\title{
Spaces of neoliberal experimentation: soft spaces, postpolitics, and neoliberal governmentality
}

\section{Graham Haughton}

School of Environment and Development, The University of Manchester, Manchester M13 9PL, England; e-mail: graham.haughton@manchester.ac.uk

\section{Phil Allmendinger}

Department of Land Economy, University of Cambridge, 19 Silver Street, Cambridge CB3 9EP, England; e-mail: pma32@cam.ac.uk

\section{Stijn Oosterlynck}

Centre on Inequality, Poverty, Social Exclusion and the City, Department of Sociology, Antwerp University, Belgium; e-mail: Stijn.Oosterlynck@ua.ac.be Received 7 March 2012; in revised form 9 May 2012

\begin{abstract}
This paper examines the proliferation of soft spaces of governance, focusing on planning. We move beyond more functional explanations to explore the politics of soft spaces, more specifically how soft space forms of governance operate as integral to processes of neoliberalisation, highlighting how such state forms facilitate neoliberalisation through their flexibility and variability. Recent state restructuring of the planning sector and emerging trends for soft spaces in England under the Coalition government proposals are discussed.
\end{abstract}

Keywords: soft spaces, neoliberal spatial governance, postpolitics

\section{Introduction}

"It is not often enough noted that the spatial geography of governance has been radically transformed in the era of the global advance of neoLiberalism. The number of units of territorial government has increased spectacularly. ... And the number of de facto spatial units of governance has multiplied far more than this if we take into account regional and urban authorities and other sub- and transnational networks."

Lovering (2007, page 359)

Over the last two decades the nature of spatial governance has changed dramatically, both quantitatively in terms of the number of units of territorial governance established and qualitatively in the ways in which multiple networks of actors are continuously made and remade to carry forward particular strategies. One important dimension of this process of transformation is the proliferation of soft spaces of governance, particularly evident in spatial planning and regeneration. 'Soft spaces' here refers to the 'in-between' spaces of governance that exist outside, alongside or in-between the formal statutory scales of government, from area masterplans to multiregional growth strategies (Allmendinger and Haughton, 2009). These spaces of governance are typically time limited and can emerge for a variety of reasons. Though brought to notice initially through UK research on planning, soft spaces appear to be an international phenomenon that exists well beyond the sectoral confines of planning, having been identified in variant forms in Australia (Searle and Bunker, 2010) and various European countries, whilst also being evident in the creation of transnational regional spaces such as the Baltic Sea and Danube Basin regions (Faludi, 2010; Luukkonen and Moilanen, 2012; Metzger and Schmitt, 2012; Stead, 2011). 
The soft spaces of governance are often counterposed against what might be termed the 'hard', statutory spaces of government; formal territorial units of government typically with legally defined and definite territorial boundaries linked to administrative structures of subnational government, and to democratic electoral processes (Haughton et al, 2010). The hard spaces and boundaries of government in the case of planning for example are typically national, regional, metropolitan, and local governments, with the responsibilities and powers of each tier set out in statute. In the case of planning these formal tiers of government provide a form of electoral accountability for the creation and enforcement of statutory local and regional plans and, more generally, national planning law. Though a useful binary distinction for introductory heuristic purposes, in practice the distinction is often less clear, as many governance spaces exhibit more hybrid or evolutionary qualities (Heley and Jones, 2012; Metzger and Schmitt, 2012).

Soft spaces of spatial governance exist both beyond and in parallel to the statutory scales of government, often involving the creation of a new territorial entity which sits alongside and potentially challenges existing territorial arrangements or the dominance of particular scales of governance. Whilst varied, soft spaces can be generally considered:

"informal or semiformal, nonstatutory spatialities of planning with associations and relations stretching both across formally established boundaries and scalar levels of planning and across previously entrenched sectoral divides” (Metzger and Schmitt, 2012 pages 265-266).

The boundaries of such spaces can also be soft or 'fuzzy' due to genuine functional and fuzzy geographies around cultural phenomena such as identity politics or natural phenomena such as estuaries or water catchment areas. Fuzziness can also be a deliberate tactic to create uncertainty or to mask clarity over whether a particular area or place is included in a policy framework or not, disrupting accountability and transparency. As such, fuzzy boundaries can be either progressive or regressive. On the positive side, using fuzzy boundaries provides the impetus to think more creatively about the policy implications of how complex functional relationships are rarely if ever contained within a particular set of boundaries. They can also be used to engender debates about new territorial identities (Paasi, 2010; Painter, 2008), rather than simply 'announcing' them in bureaucratic fashion: they create a space for debate. In this sense, fuzzy boundaries have a more progressive, inclusive potential than simply to act as spaces for deregulation. More problematic is where they blur accountability mechanisms and are used to circumvent facing up to issues that need to be addressed rather than confronting them.

The proliferation of experiments in overlapping and flexible governance spaces is sometimes explained in functional terms. Some policy makers argue that there is a functional mismatch between traditional and fixed administrative boundaries with the realities of how labour, travel to work, and housing markets work and interact (Waterhout, 2010; Haughton et al, 2010). They can also arise because of the difficulties of aligning statutory administrative boundaries with those of ecological systems such as river basins (Davoudi and Strange, 2009). Alternatively, they can be seen as shadowy spaces for legitimating deals and understandings by a mix of elected and unelected actors, leading to a process of 'validation creep' between nonstatutory and statutory plans (Allmendinger and Haughton, 2009; Haughton et al, 2010). There may be other rationalities at work too, resulting in a wide range of discursive framings and concrete institutional forms. In the case of planning, for instance, the diverse drivers include the 'Europeanisation' of spatial planning, with its emphasis on relational thinking; the influence of 'data-led' scales and spaces (eg, NUTS 2 and 3 regions); and the creation of spaces for the purposes of apportioning and delivering EU and other regional development funds (Faludi, 2010; Stead, 2011; Waterhout, 2010). 
In some cases the new soft space forms of governance were clearly positioned as experiments in new spatial thinking allied to attempts to develop new territorial identities; an openness sometimes signified by the use of fuzzy boundaries, for instance in the early maps produced in developing the Wales Spatial Plan and the use of city regions in England's Northern Way (see Harrison, 2010; Haughton et al, 2010; Heley and Jones, 2012). The use of fuzzy boundaries in such cases seems to have been a deliberate tactic to help destabilise the centrality of existing territorial forms and to generate debate around alternative scales and spaces, often positioned as a prompt to creativity and innovation. One striking use of fuzzy boundaries is evident in official attempts to create new cross-border identities by the European Commission, as part of an effort to open up debates addressing boundary problems particularly in peripheral areas, and also the creation of mesoregional European identities, such as the Danube Basin region (Dühr, 2011; Stead, 2011). Some of these 'soft' spaces appear to undergo a process of 'hardening' up over time (Heley and Jones, 2012; Metzger and Schmitt, 2012), whilst others prove more ephemeral and disposable, in policy terms.

In some circumstances, where there is a functional spatial justification for the emergence of a new soft space governance formation, such as for the purposes of subregional or metropolitan strategic planning, the relation between the higher scale soft space and lower scale statutory spaces of planning is informative: a subregional plan has no statutory status but can be prepared cooperatively between authorities to provide a strategic, multisectoral vision that informs and coordinates statutory plans. In other circumstances, the relationship will be very different. Nationally inserted soft spaces such as enterprise zones or development corporations can exist as 'black holes', working in isolation from statutory spaces. Here, the relationship is one of disruption or experimentation forcing a new way of working or set of priorities upon an area. In other circumstances such soft spaces of delivery can be developed in partnership and seek to assemble land, create a consensus around a scheme, and garner private sector confidence and finance. At the regional scale, soft spaces can be deployed to address particularly sensitive, cross-boundary issues that statutory plans linked to accountable and transparent processes would find difficult to tackle.

Territorial politics can make functional planning across and between existing political, legal, or administrative spaces difficult if not unacceptable. Creating non-statutory vehicles for thinking that sidestep such sensitivities can create a new space for debate and thinkingthe downside being that they can also be used to sidestep difficult issues. An example would be the creation of a subregional plan for the boundary area of northwest England and northeast Wales, which raised concerns that policies were being developed through such systems that ignored sensitive issues of national and linguistic identity, which were then transposed rather uncritically into formal statutory plans in a form of 'validation creep' (Haughton et al, 2010).

Rather than rush to judgment here, we want to argue that the new state spatialities represented by soft spaces of governance are of themselves neither a good nor a bad thing. These new experimental spaces and extant politico-juridical spaces exist in symbiotic relationship to each other, such that they always need to be seen as coconstituted in pursuit of particular state strategies. This makes the key analytical challenge one of understanding how particular governance assemblages come to be formed, in relation to which types of state strategy and in pursuit of what kinds of politics. In the following sections we develop an argument that soft spaces reflect the postpolitical tendency towards continuing experimentation in market-based forms of governance. We start our analysis by drawing upon governmentality studies and state-theoretical approaches to state spatial restructuring, grounding these in an ontological notion of politics derived from postfoundational political thought which focuses on the various ways in which political antagonism is displaced (Marchart, 2007). This allows us to explore the challenges to democratic politics that are connected with the reworked 
governance spaces associated with the planning system in England. Finally, we reflect upon some ongoing changes to planning under the UK Coalition government's Localism agenda, advancing some possibilities around new and emerging forms of soft space governance.

\section{Rationalities of soft space governance}

Approached from the perspective of state spatial theory, soft space forms of governance are new state spaces that can be seen as an integral part of turbulent institutional dynamics driven by neoliberal regulatory restructuring in pursuit of a high growth agenda for nations, regions, and localities, in which new policies and institutional forms can be rapidly created, mutated, and discarded (Brenner, 2004; Peck, 2010). One outcome of this febrile approach to policy making and institution making is the systematic production of geoinstitutional differentiation (ie 'variegation') (Brenner et al, 2010a). The highly variegated nature of neoliberalisation is, in this account, an essential feature of its evolutionary and resilience capacity. With continuous policy experimentation and institutional reform at its heart, neoliberalisation is not simply an 'out there' ideational driver of change, it is a process that is inevitably mediated through diverse local experiences and institutional structures, memories, and traditions, creating variegated experiences between places and through time (Brenner et al, 2010a; Peck and Theodore, 2007). Whilst the scope for variegation is circumscribed by the operational logic of neoliberalisation, the collision with and mediation through existing regulatory landscapes, the particularities of place and divergent contexts mean that differentiation is inevitable, though not predictable (Brenner et al, 2010a; 2010b). The unleashing of multiple subnational experiments in neoliberalised policy making in this sense is a constitutive part of neoliberalisation, not simply an outcome reflecting local contingency. The question then becomes how the systematic production of geoinstitutional differentiation under neoliberalism can be unpacked to see how it actually works.

One potentially useful way of doing this involves drawing on recent work on neoliberal governmentality, which draws on a Foucauldian 'analytics of government' framework based on the detailed study of a range of material and symbolic technologies for influencing the behaviour of individuals and institutions. This framework highlights the role of "a complex of practical mechanisms, procedures, instruments, and calculations through which authorities seek to guide and shape the conduct and decisions of others in order to achieve specific objectives” (Lemke, 2007, page 50). Crucially, these are not necessarily imposed from outside; there may also be an element of individual and institutional self-government, involving a realignment between political rationalities and technologies for the regulation of the self, not least the ascendancy of ideas that prioritise the actions and motives of the individual active citizen over previous notions of the social citizen with powers and obligations derived from attachment to a collective body, or society (Rose and Miller, 1992, page 201). Governmentality is thus seen both as internal and as external to the state, involving a continuous redefinition of the role of the state, not least the boundaries of the public and the private (Lemke, 2007). This manifests itself in a shift from formal to informal techniques of government, involving selected new actors, though not necessarily with any diminution in the role and capacity of the state, rather a new relationship between the state; the market, and civil society actors. What emerges is an understanding of the state as something that is perpetually in a position of becoming, whose institutional forms and capacities are always both transient and historically and geographically contingent.

Neoliberal governmentality in this context refers to the ways in which various forms of neoliberal rationality are mobilised by and through the state, involving a range of governmental technologies. Specifically, neoliberalism reactivates scepticism about the capacity of political authorities to govern well, advocating various forms of commodification, marketisation, and reworking regulatory and other institutional arrangements to reconfigure 
the relationship between the state and individuals (Rose and Miller, 1992). Dominant (neoliberal) rationalities have consequently been absorbed and transformed into a variety of individualised and institutionalised routines that variously disrupt unwanted behaviour and justify, normalise, and reward preferred behaviours. This is evident in the marketisation of planning, for instance, as fiscal incentives are introduced to speed up planning or to encourage communities to accept new housing. The value of this analytical approach is that, "Instead of taking institutions as the point of departure, it focuses on technologies that are materialized and stabilized in institutional settings" (Lemke, 2007, page 50).

Drawing on Lemke, soft spaces can be understood as a form of neoliberal govermentality, involving not so much:

" a diminishment or reduction of state sovereignty and planning capacities but a displacement from formal to informal techniques of government and the appearance of new actors on the scene of government (eg, nongovernmental organizations) that indicate fundamental transformations in statehood and a new relation between state and civil society actors" (Lemke, 2002, page 58).

There is a valid question here about whether soft spaces constitute a new or necessarily 'neoliberal' form of governmentality, or whether they represent a continuation of longer stranding trends within spatial governance. We want to argue that, whilst planners have always worked informally and sought to coordinate activities arranged across multiple forms of administrative geographies (for instance, public utility companies), what we are seeing is in fact distinctive, new, and still evolving. In this interpretation, whilst soft space forms of governance have undoubtedly existed in the past, for instance the UK's New Town Development Corporations in the 1950s-1970s, they were embedded within a different, more hierarchical politics, where the authority of national and local government remained largely unchallenged by them. The New Towns were less a function of the rescaling of the state, more a limited and bespoke response to a particular set of policy and delivery challenges, addressed by creating a new state vehicle for the exercise of what were largely seen at the time as state functions.

The kinds of soft spaces we are witnessing now are more varied both in rationale and in function, but underlying this variety is a different kind of politics. In the literature on state spatial restructuring and neoliberalisation, this new kind of politics is characterised in terms of decreased confidence in government as arbiter and deliverer of improved lives. Since the 1970s, as the foundations of the postwar welfare state settlement came under fundamental challenge, there has been a major rethink of the relationship between the state, market, and civil society, where the state has not so much shrunk as reformulated its rationale and role from being arbiter and provider of key forms of collective infrastructure, preferring instead narratives such as enabling, facilitating, guiding, coordinating, occasionally stimulating. Perhaps not coincidentally these are terms that planners too have adopted, as they have recast their role to fit in with changing societal expectations.

Although this argument adequately characterises the change in politics since the rise of neoliberalisation on the ontic level of concrete policy orientations, it does not reflect on the ontological foundations of the politics of neoliberalisation [see Mouffe (2005) for the distinction between ontic and ontological perspective on politics]. Interestingly, Lemke (2007) goes some way in the latter direction by suggesting that there is a link between the rise in interest in governance systems and the emergence of discourses around the 'end of politics' and postideological thinking, with their emphasis on coordination, integration, and consensus building and the move away from supposedly outmoded adversarial forms of politics. 
"Seen from the perspective of an analytics of government, the governance discourse represents a particular 'art of government' that is firmly rooted within a liberal concept of the state. It stresses political consensus, mutual accommodation and collective problem solving and searches for mechanisms that foster coordination, cooperation and harmonization. The governance discourse translates fundamental antagonisms and political oppositions into modes of articulation of different interests. It conceives of strategic confrontations as diverse 'inputs' to reach a decision or to carry out a programme" (Lemke, 2007, page 55).

Lemke here couples a focus on the concrete and readily observable modalities and strategies through which politics is played out on a day-to-day basis with a concern for the ontological foundation of the political. The fundamental antagonisms that divide society form the ontological foundation of the political (Mouffe, 2005; Oosterlynck and Swyngedouw, 2010; Rancière, 1995; 1999, 2001). This raises questions about how soft spaces, particularly as they relate to spatial planning and regeneration, deal with those antagonisms that give rise to incommensurable demands. Do they foreclose or displace this proper political dimension by installing modes of governance based on consensus seeking and stakeholder deliberation, market competition and incentives, or the invocation of local communities and direct democracy? Or, do soft spaces create a space for the free expression of political antagonisms by treating everyone as equal speaking beings?

From this perspective the proliferation of soft spaces could be seen as changing what Rancière $(1995$; 2006) calls the 'partitioning of the sensible' in spatial development. Every governmental configuration distributes names, places, and functions, which determine what is visible and sensible and what actions are deemed appropriate. Soft spaces install a new partition of the sensible by defining particular subjects as stakeholders (eg, the state as in need of collaboration with the private sector or civil society, business as benign and acting in the general interest, local communities as harmonious entities). All this is not essentially different from what a governmentality approach could offer us, but Rancière moves us beyond this when he explains where politics proper comes from; namely, the disruption caused by the demand for equal voice from those with no voice and place in the current partition of the sensible. This demand for equality cannot be accommodated within the existing sociopolitical order, but requires its wholesale transformation. Politics proper then is not about the negotiation of particular demands, but is about a process of political subjectification that involves the translation of particular demands (interests) into universal demands, implying a wholesale critique of the social order and its naming and placing of subjects.

Although soft spaces allow for a diversity of actors to be involved in the governance of space, this participation does not necessarily produce politics proper. We would suggest here that soft spaces, to varying degrees, allow for particular demands to be voiced and negotiated, as long as they do not question and disrupt the overarching framework of marketled development. The collaborative and consensus-seeking stakeholder arrangements of soft spaces welcome, and even thrive on, the pluralisation of demands but work to turn these into particular demands that can be calculated and weighted against other particular demands, while at the same time preventing their translation into universalising demands that cannot be accommodated for in the current social order. This ontological perspective on politics is highly relevant for spatial planning, a practice that has always been situated in the field of tension between politics proper and policy making (Swyngedouw, 2007). Whereas its strategic dimensions explicitly aspire to imagine and open up radically different spatial futures and transformation (Albrechts, 2006), its action orientation is necessarily about closing down the plurality of possibilities and establishing (a singular) order in space. We argue here that soft spaces tend to not mediate this tension in a proper political way by allowing for a genuine 
politicisation of the debate on how to organise space, but instead selectively open up state space for particular interests to be included and negotiated with within a market-oriented framework of spatial development.

\section{Evolution and institutional experiments in planning as a form of spatial governance}

Our starting point in this section is that neoliberalism provides a broad, abstract philosophical base for the emergence of recent policy, but how it has been interpreted and translated into policies, programmes, and institutions has changed over time, requiring attention to identifying the mechanisms through which neoliberal thinking is translated, codified, and operationalised at national and subnational levels. We set out here to examine how these processes have worked through in English planning, where over thirty years of reforms have generated a continuous reworking of the formal or statutory scales of planning and emergent 'soft space' arrangements. Although English planning remains a relatively hierarchical form of government, reflecting the contentious nature of development decisions and the need for judicial remedy in extreme cases of dispute, it has also taken on aspects of 'governance', as increasing efforts are made to engage with multiple actors and agencies in developing and agreeing both to formal statutory plans and to nonstatutory spatial strategies (Tewdwr-Jones, 2002; Vigar et al, 2000). As a consequence, governance is increasingly a feature both of the statutory and of the nonstatutory workings of planning, as part of a pervasive rationality to improve partnership working between government and selected 'stakeholders'.

The part played by path dependency is crucial to understanding both the emergence and the uneven rollout of governance experiments, not least how new combinations of soft space and statutory planning spaces emerge over time. Adopting a reasonably long-term perspective helps to highlight the evolving rationalities deployed over time by those promoting soft space forms of governance in the planning system, in particular how the mistakes of previous experiments are (selectively) learnt from. This focus on evolving rationalities helps us to see how the broadening involvement of new private and civil society actors in these new soft spaces of spatial governance does not necessarily lead to a proper politicisation of spatial planning strategies. Contrary to much thinking about spatial planning and its governance as being more inclusive than 'top-down' or hierarchical forms of planning, and hence intrinsically more democratic, we argue here that it is not the degree of inclusion, but rather its openness towards disruption through the staging of dissensus, that is indicative of the properly political nature of soft spatial governance. This shift in emphasis is profound, as it implies a focus on how the shifting configurations of soft and hard statutory planning spaces in the British planning system deal with the political antagonisms inherent to spatial development and the various ways in which these antagonisms are addressed, whether dismissed, displaced, or simply distanced from.

Figure 1 provides a thirty-year plus overview of the evolution both of statutory or hard spaces and of informal or soft spaces in English planning, using a four-fold periodisation. The dates of this periodisation are illustrative rather than definitive-in practice, elements of old and new approaches seep across any such artificial boundaries, not least as even radical new governments take their time to phase out certain projects associated with the previous regimes. The diagram schematically illustrates how the different spaces and scales of planning combine together at different moments in time. We can begin to see from this the continuous rescaling of planning in this period, and that whilst particular policy scales may be privileged at particular moments, for instance the regions under New Labour, it is always necessary to see how multiple hard and soft planning spaces work together. In the Westminster model that still characterises the UK state, the orchestration of the rescaling of such privileged scales is principally in the domain of national government, so in that sense the national scale is always dominant. 


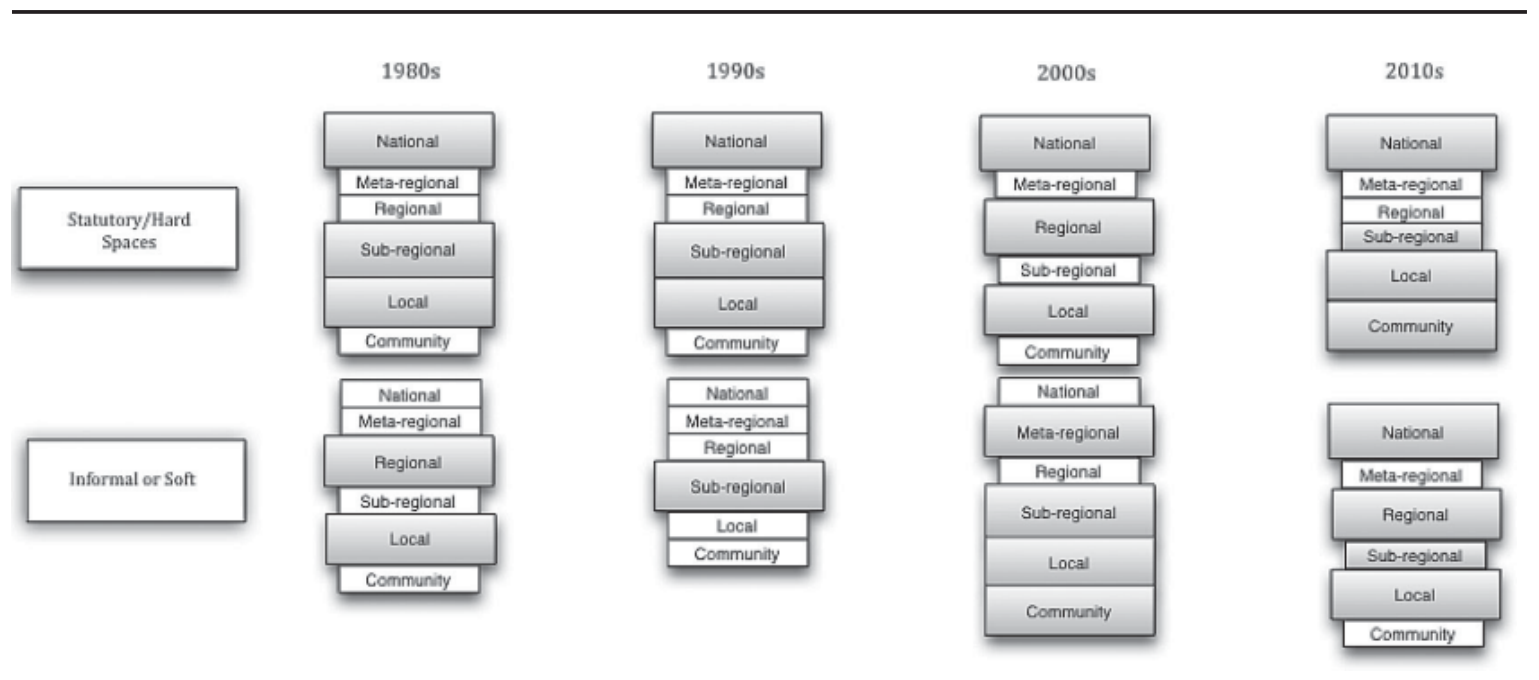

Figure 1. Evolving formal and soft spaces of planning. Different sized boxes are intended to indicate relative actual and symbolic importance of particular scales in each period.

Each of the four periods identified in figure 1 embodies distinctive governance arrangements in which hard and soft spaces are combined in pursuit of growth. To try to understand more about the rationales for this it is helpful to contextualise it in terms of how neoliberal thinking and new practices evolve and mutate in response to the emergent contradictions and crises of earlier approaches, both in broad ideological terms and specifically in relation to the supportive geoinstitutional architectures.

For example, the 1980s early experiment in 'roll-back neoliberalism' saw planning powers reigned back in, rhetorically presented as a move away from excessive red tape and state bureaucracy (Peck and Tickell, 2002). The planning profession was also accused of trying to work against the market, and of being oblivious to the realities of rapid market change in an increasingly globalised economy. The result was a reinscription of the role of planning as essentially a land-use regulatory tool, and a parallel reworking of the tools and technologies of planning, not least a shift away from long-term, visionary regional plan making. Instead, the Thatcher government introduced a national presumption in favour of development weighted to favour developers. This presumption undermined the hard spaces of local plan making by encouraging developers to ignore local statutory processes and to use the appeal process. Simultaneously, localised soft space experiments in deregulation were set in train such as Enterprise Zones (EZs) and Simplified Planning Zones (SPZs), whilst Urban Development Corporations (UDCs) shifted planning powers from elected local authorities to business-led UDC boards. In rhetorical terms, planning and the state were presented as the problem for areas facing economic decline, not the solution, so instead new governance arrangements were introduced to reduce 'red tape', empower individuals, and draw on entrepreneurial initiative (Allmendinger and Thomas, 1998; Thornley, 1993). The new governance arrangements were rarely coterminous with existing local government boundaries, instead creating 'enclaves' within them, raising concerns that they were in effect 'Trojan Horses’ for external intervention (Haughton, 1999).

The shift towards experimental deregulatory spaces in this period was very much about 'winning the argument' that market-led approaches were more effective and efficient than state-led redevelopment initiatives. Ironically, however, the new 'deregulatory' experiments frequently involved highly interventionist strategies of public sector fiscal incentives, infrastructure provision, and land assembly. Even at the peak of 'roll-back' neoliberal experimentation (Peck and Tickell, 2002), the statutory spaces of planning could not readily be sidestepped, given their role in providing a level of local legitimacy and accountability to the planning system. Critical here was the public concern in mainly Conservative voting areas 
about a 'planning free for all' and the desire to restrict certain forms of new development, particularly new housing on greenfield sites. Wider disquiet over the diminished local control of planning was accompanied by the concerns of landowners and developers about the market uncertainty outside of the experimental areas' deregulation of planning controls. Government began to feel pressure from developers who wanted better regulated land supply and certainty over future development patterns to help manage risk in a cyclical property market (Peck and Tickell, 1992; 1995).

By the 1990s as some of these issues and contradictions came to a head, a form of selective market-supportive state reregulation or neoliberal 'rollout' (Peck and Tickell, 2002) took place, as UDCs, EZs, and SPZs were largely abandoned. Regional planning started to reappear on the agenda, along with tools such as housing targets to try to ensure that housing provision was focused on areas of highest demand, such as the South East. The presumption in favour of development was replaced by the presumption in favour of the development plan - a subtle but important change that represented a return to more centralised state control over development priorities. Facilitating growth was still very much the objective of planning but it would be more rational, technocratic, and planned through the formal scales of planning.

The election of New Labour in 1997 saw both a consolidation and an extension of this direction of travel. The initial privileged scale in the reworking of subnational governance was the regional level, with the strengthening of regional planning and the associated governance structures of regional assemblies and their successor bodies. Even more important perhaps was the creation of nonelected Regional Development Agencies to lead on economic development with strong business representation and increased funding and responsibilities gradually devolved to them. Separate arrangements were put in place in Greater London to strengthen democratic representation, including the elected Mayor and the creation of an elected Greater London Assembly, which together worked on economic development, transport, and planning issues for the capital. The regional planning system was subject to successive reforms to make it more powerful, including giving regional spatial strategies a statutory basis from 2004. Regional planning was also the site of experimentation with new planning technologies, involving greater participation of stakeholder bodies in plan making, improved systems for monitoring, and the introduction of sustainability appraisal (Counsell and Haughton, 2006; Haughton and Counsell, 2004; Inch, 2010).

New Labour's multiple planning reforms signaled a growing discontent with the speed of change within the planning system and its apparent inability to deliver the scale of changes desired (Allmendinger, 2011). This partly helps to explain the emergence of attempts to reform planning by encouraging the creation of parallel forums for engaging in spatial thinking. From the early 2000s the government unveiled a succession of metaregional soft spaces to provide high-level visions and alternative lower level delivery mechanisms for functional economic planning. Classic examples of this were three of the government's growth areas announced in the Sustainable Communities Action plan (ODPM, 2003): 'Milton Keynes and South Midlands', 'London-Stansted-Cambridge-Peterborough', and the Thames Gateway (Haughton et al, 2010; Raco, 2005). The same government initiative also saw the creation of Housing Market Renewal Pathfinders in various parts of the North and Midlands where dysfunctional housing markets were associated with problems of abandonment and dereliction. Shortly afterwards, in response to political claims that the growth potential of the North was being ignored, the government invited the three Northern regions to combine to create their own pan-regional Northern Way strategy. A key feature of this plan was the creation of eight newly imagined city regions with fuzzy boundaries, put forward as the economic drivers of the North. 
What is significant about all these is that they were for the most part high-profile national initiatives which aimed to 'draw down' government infrastructure investment in order to promote housing or economic development and to facilitate above-trend house building. Most importantly, these new economic spaces were created over and above New Labour's regional apparatus. They were expected to inspire fresh spatial thinking, which the government made clear it wanted to see reflected in statutory regional and local plans.

Following reissued planning guidance in 2004, a range of subregional soft spaces were created as the building blocks of regional spatial strategies, since many regions covered areas too disparate to be considered as single functional entities. The creation of subregional approaches was deemed particularly relevant where boundary issues existed between neighbouring regions. Reflecting both the rejection of the idea of elected regional government in a referendum in the North East and with it the growing sense that the regional experiment has perhaps reached its limit, increasingly the subregional debate came to focus on the importance of city regions (Haughton and Counsell, 2004; Haughton et al, 2010). The result was the creation of a multiplicity of new subregional and local bodies beyond the statutory planning system being asked to think strategically and spatially.

With powerful new discourses in public policy such as social exclusion, sustainable development, and climate change, it became necessary in this period to temper early deregulatory initiatives and high economic growth rhetoric with greater attention to social justice and environmental issues. Responding and indeed contributing to the changed mood music, political discourse became enamoured of working in partnership, building consensus, and joining up, coordinating, and integrating policy. Continuing experiments in 'rollout neoliberalism' constituted a response to this changed climate, involving a rethinking of the role of the state as partner and providing long-term visions and frameworks, and in the case of planning promising to revamp the system by recommitting it to the pursuit of growth whilst making it faster and fairer. In the process, alternative discourses such as low growth, no growth, or degrowth (Martínez-Alier et al, 2010) became all but unmentionable in professional planning circles. The ecotowns experience is illuminating in this regard; a new form of competitive opening up of the creation of new planning spaces, which it was hoped would help sidestep some conventional planning requirements. New Labour announced a competition for up to ten New Towns in 2007, inviting ideas from local authorities and developers, promising that ways would be found to work the new developments through the planning system expeditiously. This competition provoked a rush to capitalise on land assets by some landowners and local authorities, often in alliance. This in turn provoked some fairly conventional community protests against the proposals as they emerged and a conventional backtracking by the government about applying high ecostandards and allowing developments to proceed without proper negotiations with local players. The radical potential of ecotowns as both an experiment in sustainability and in planning was soon lost. Though four ecotown sites were announced in 2009, in the context of a recession and limited support from the new government, progress has been slow.

The influence of neoliberal thinking on planning has been fast mutating, multidimensional, and multidirectional, sometimes coming back to early 'unfinished' projects, as with UDCs which were reinvented in 2003 and EZs reinvented in 2010 (Haughton, 2012; Hildreth and Bailey, 2012). Understanding this process requires analytical attention to how neoliberalism as a political project, involving particular strategies of spatial-economic development and associated regulatory forms, is ridden by contradictions and crisis tendencies. The political antagonisms that feed on these contradictions and crisis tendencies challenge the continued viability of neoliberalism and therefore are continuously displaced and residualised, evident 
in the shifting mechanisms through which neoliberal thinking is translated, codified, and operationalised at national and subnational levels.

Soft planning spaces have played an important role in mediating and translating neoliberalism, providing flexible and ephemeral experimental spaces and alternatives to costly and disruptive reorganisation of hard, statutory spaces. During the 1980s, politically disruptive antagonisms over development driven planning agendas were residualised by the deliberate undermining of local statutory processes and the imposition of the facilitation of development as the overarching goal of the planning system. As the introduction of deregulated experimental soft spaces gave rise to legal uncertainties, and concerns about local legitimacy signaled the return of political disagreement, a reregulation of planning took place, albeit within the same neoliberal development friendly framework. In the early 1990s this reregulation was pursued through the reinforcement of subnational statutory planning spaces and central state control (the development plan). From 1997 onwards, New Labour further pursued a reregulation strategy by opening up the planning system to a host of new stakeholders and noneconomic concerns and establishing a range of subnational new governance initiatives. This reregulation did not, however, open up spatial planning to politics proper, but through a stress on consensus building, partnerships, and integration focused on more effective 'delivery' of growth and thus diffusing political tensions around the potentially contradicting aims of social justice, sustainable development, and economic growth.

\section{Soft planning spaces under the Coalition government}

In this section we focus on the shift from the planning system associated with the final years of the New Labour era to the policies of the Coalition government. Since its election in May 2010, the Coalition government has set out its agenda for a dramatic reworking of planning, including some of its privileged scales, notably with the abandonment of regional planning and the insertion of a strengthened neighbourhood scale (figure 2).

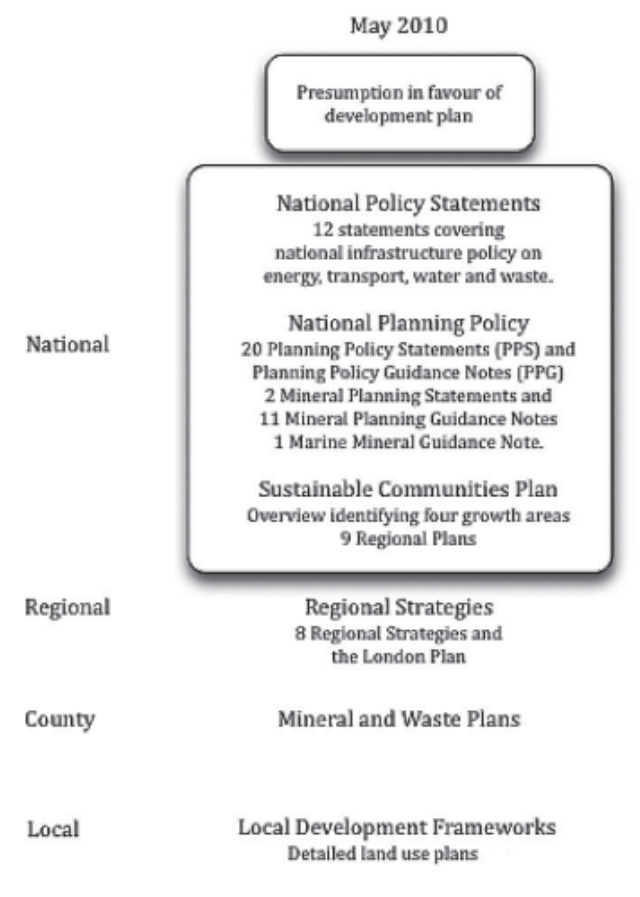

Neighbourhood

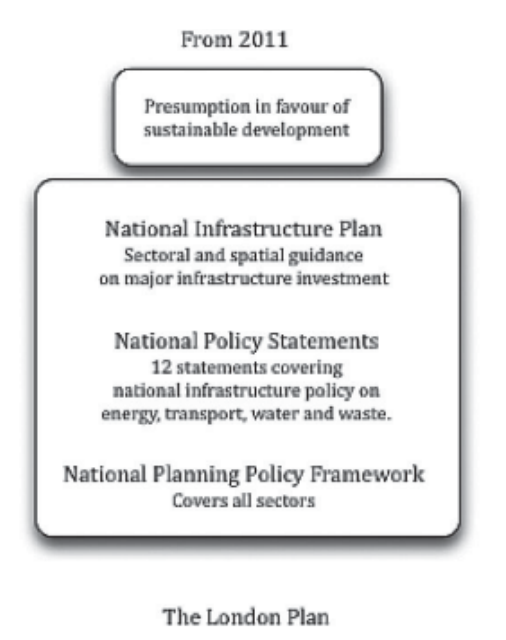

Mineral and Waste Plans

Local Enterprise Partnerships Covering sub-regional areas

Figure 2. Previous and Coalition formal scales of planning. 
The drivers for this scalar reworking only partly concern the recession. As significant to the emerging changes are the reactions against the previous growth agenda in certain, mainly southern England locations and antagonism towards the erstwhile 'top-down', target-driven regional approach of New Labour (Conservative Party, 2010; HM Government, 2010a). The reaction against the previous regime neatly illustrates the need for the planning system to be both effective and carry legitimacy, echoing the experiences of the 1980s.

Broadly, the changes under the Coalition involve four main shifts from which we can already identify new soft space governance arrangements, their governance rationalities, and how they engage with the political. First, there is a reorientation of national planning, away from detailed national planning policy guidance and plans towards a slimmed down, single overview national strategy document (Communities and Local Government, 2011; HM Government, 2010b). As national planning guidance becomes more selective and focused, politicians argue that discretion is increased at the local level, moving from a prescriptive approach to one that ostensibly at least seeks to move away from the 'top-down' imposition of national policy and targets. This in turn, it is argued, empowers local authorities to make policy without always having to check with central government that it is acceptable, embodied in the new 'general power of competence' granted to them (from February 2012) to act as they see fit, provided it is not expressly forbidden in statute or statutory guidance.

The second main shift involves a dismantling of New Labour's regional institutional architecture with the dismantling of Regional Development Agencies and Regional Assemblies, along with their strategies and the housing targets they contained. The exception is London, which will retain its 'regional' roles in planning and economic development. Third, there been the creation of new functional spaces at the subregional level through the creation of Local Enterprise Partnerships (LEPs), plus a new 'duty to cooperate' between local authorities contained in the Localism Act 2011 (HM Government, 2010b). The LEPs are a new form of subregional soft space governance that transcends individual local government areas, created with an initial mandate to draw on business expertise to deliver economic development and with the prospect offered of being able to get involved in subregional planning. Thinking beyond local authority boundaries was a key rationale for introducing LEPS (Hildreth and Bailey, 2012). In calling for coalitions of the willing to come together to propose LEPs, the government sought to be nonprescriptive in the geographies of these new entities, so in some cases for instance they overlap. Likewise, the government left it to local actors to determine which policy arenas they would prioritise, so some might engage in more spatial strategy work than others, for instance. In practice, however, a certain disciplinary power remains with central government, which controlled the designation of LEPs and retains discretion to reward favoured LEPs financially, for instance with the creation of Enterprise Zones in their area, a 1980s policy reminted for the current era.

Finally, the government chose to privilege the neighbourhood scale of planning, operating below the local authority level, allowing communities to prepare their own neighbourhood plans. Although rhetorically presented as a form of community empowerment, they will need to conform both to up-to-date Local Development Frameworks and to national policy. Because these will be voluntary, an uneven mosaic of neighbourhood plan coverage is anticipated, with as yet unclear knock-on effects for those areas that do not produce them (Haughton, 2012). Neighbourhood plans will be subject to independent examination and, in a new departure for English planning, direct democracy will be invoked with the requirement that they be put to a local referendum where a simple majority in favour will be required. Relatively small numbers of local businesses or local people will be able to come together to prepare such a plan. Some areas might then see competing local plans. The geographies of neighbourhoods is again left open to local discretion, so neighbourhood plans could involve just one ward or 
parish, or combinations of them. Some neighbourhoods will not produce plans. Rather than seeing this as a matter for public hand-wringing, civil servants and ministers say it should be celebrated. The logic here is that such neighbourhoods will still be covered by the policies of the local authority plan, so we should assume that they are content with this state of affairs (Haughton, 2012).

Democratic deficits are at the heart of the Coalition government's public rationale for dismantling much of the previous planning system, including the regional planning architecture of New Labour based on unelected regional assemblies. This system was quickly declared undemocratic and discarded, with the exception of Greater London where there was a democratically accountable body responsible, namely the Mayor and Greater London Assembly. There has been a parallel dismantling of much of the associated metaregional and subregional soft space governance architecture, such as the Northern Way and Housing Renewal Pathfinder areas. The cumbersome, target-driven system of Local Area Agreements and Multi-Area Agreements created by New Labour is now defunct.

What we are witnessing is a new form of governmentality in the making, one which excoriates the target culture and democratic deficits of the New Labour approach, and instead envisages a stronger role for local actors to create locally distinctive planning arrangements that in theory are less tied by national policy directives (Haughton, 2012). In the wake of the reworking of the statutory geoinstitutional architecture of planning we can already begin to see new opportunities emerging for experimentation with soft space forms of governance. Figures 3 and 4 provide a summary of the soft space forms associated with both eras, highlighting the changes that are now underway.

Several challenges and opportunities emerge from this new policy direction, not least in relation to the remaking of soft space forms of governance. Firstly, the shrinking of national planning policy will in principle increase the discretion afforded to planners at a variety of scales to experiment and to promote ideas from a wide range of sources, not just government advice. However, planning, like nature, abhors a vacuum. So any policy reworking that

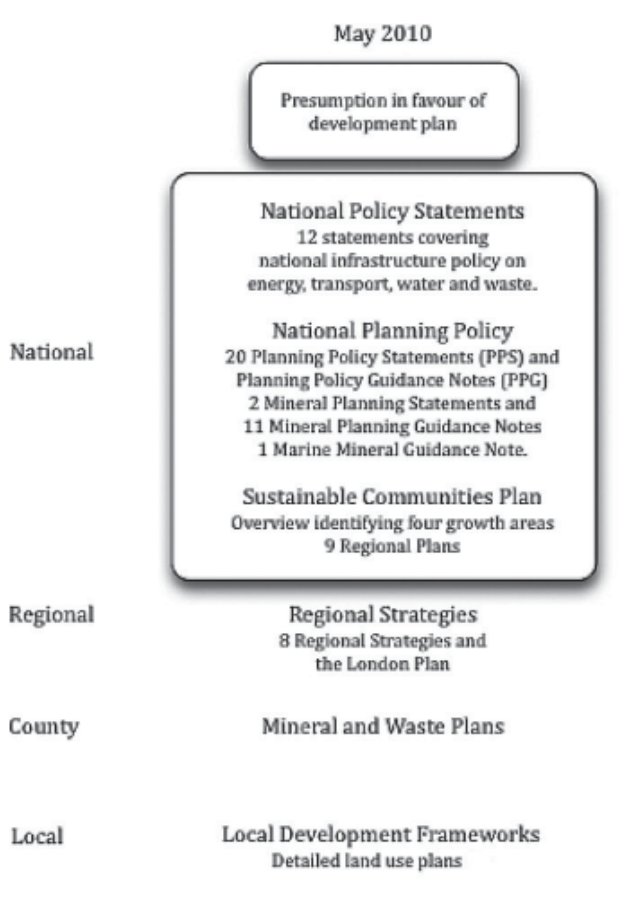

Neighbourhood

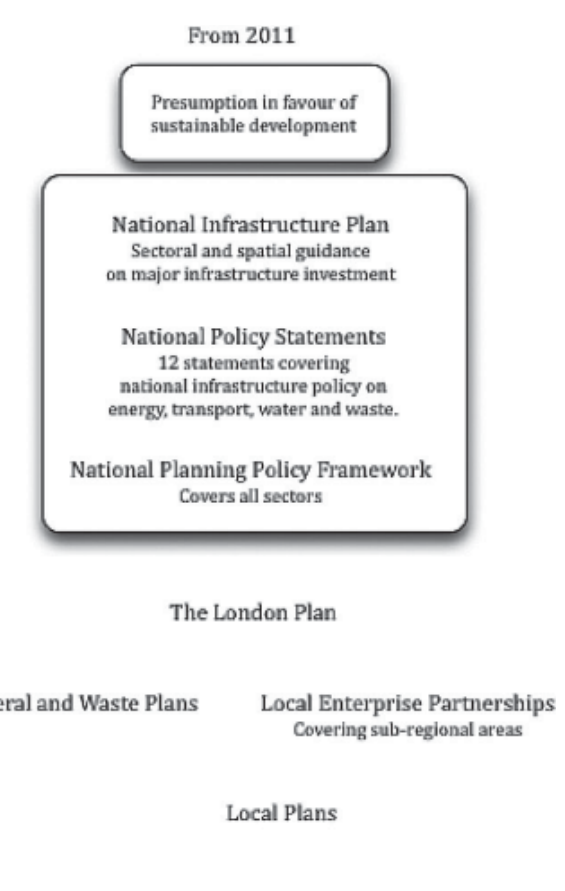

Neighbourhood Plans and Development Orders In conformity with Local Development Plans

Figure 3. Soft spaces of planning under New Labour. 


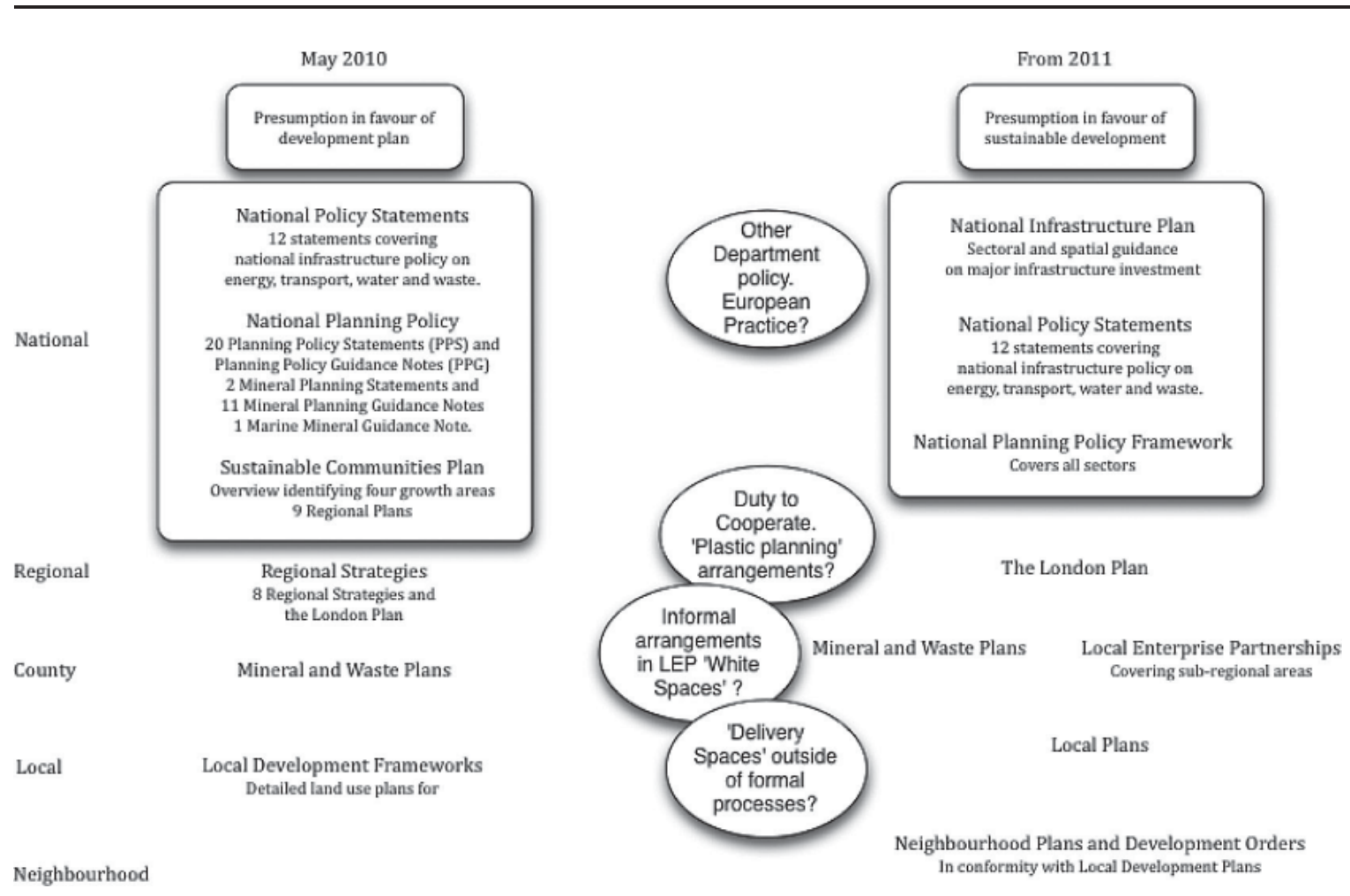

Figure 4. Possible soft spaces under Coalition government.

dismantles some aspect of planning will often see some other mechanism emerge to 'fill' the gaps, or to link the remaining pieces.

Secondly, the variability in the nature and objectives of LEPS and the uneven rollout of neighbourhood plans has the quite deliberate aim to create unevenness in policy domains and institutional coverage. Some LEPs will engage with planning more than others. Some neighbourhoods will develop their own plans, others will not. Informal arrangements between local authorities and between contiguous neighbourhoods are already emerging free of the formal government requirements - in the North West, local authorities have chosen to continue to work together on regional planning for instance. Such spaces are plastic and adaptable to local circumstances, though they may not be eligible for central funding.

The third challenge will come from the new 'Duty to Cooperate', which requires local authorities and other public bodies to cooperate across administrative and institutional boundaries. This could again lead to a patchwork of spatial and nonspatial plans with different combinations of public and private bodies involved. Evidence is already emerging that some local planning authorities are having difficulty now in proceeding with large development sites, particularly those which cross juridical boundaries, leading some to conclude that the new duty is a poor substitute for effective regional planning (Gallent and Hamiduddin, 2012). The fourth set of challenges and opportunities comes from the potential for neighbourhood experimentation around spaces of delivery and spaces of resistance. One outcome could be the emergence of 'spaces of resistance' to certain types of development in some communities; in the process making other places (those without community plans) more likely to be the focus of such new development activity. Alternatively, progrowth regimes could arise to prepare delivery focused community plans. Other spaces are also possible.

Whilst the political emphasis is on the discretion being allowed to such partnerships, in practice the tone will be set by national policy directives. The new governmentality that is being created involves a nationally dictated return to a 'presumption in favour of development' last experienced during the 1980s, with the intention to use planning to expedite rather than control development. Interestingly however it has been rescripted as a 'presumption in favour 
of sustainable development' to reflect contemporary environmental and social concerns around growth. Moreover, communities will be financially rewarded for approving new developments through the return of taxes for a time-limited period; a classic neoliberal form of rationality and governmentality, based on a reworking of the cost-benefit nexus. In effect it is a further step towards the marketisation of planning, which raises important issues about its ability to act as an independent regulatory function that traditionally has been presented as a form of protecting the public good.

The Coalition's proposals leave the main levers, tools, and objectives of planning largely in place. Neighbourhood Plans provide for experiments in delivery and engagement rather than formal spaces of resistance, as they have to fit within national and local growth-led objectives and plans. Politicians speak of some toleration of variance from the mainstream whilst arguing that local policies will need to reflect the reduced levels of higher level policy. In effect, variation is encouraged where it enhances higher levels of development and is likely to be squashed where it seeks to threaten development. All this suggests not a return of healthy democratic disagreement at the heart of the planning system, but instead a deepening of its postpolitical condition. The invocation of the local community, through procedures of direct democracy, to redress the perceived democratic deficit of bureaucratic spatial strategy making under New Labour, may effectively open up space for political antagonism, but seems uncritically predicated upon the view that the local community is the natural seat of democratic politics. It is more likely instead that local experimentation and unevenly rolled out institutional planning arrangements within a framework of market incentives and a nationally dictated presumption for development will serve to displace political disagreement through market competition for development and the capture of the 'voice' of local communities by local elites.

\section{Conclusion: neoliberal trajectories and the rise of soft space planning}

This paper points to the contemporary restructuring of planning as being part of the ceaseless search for new forms of neoliberal spatial governance, continuously adapting over time to reflect emerging understandings of the appropriate role of the state in capitalist societies.

Our analysis has sought to make explicit some of the linkage work of soft spaces as a form of neoliberal spatial governance. In particular, we argue that experiments with soft spaces represent a particular form of neoliberal governmentality and displacement of political disagreement, involving a roiling entanglement of direct interventions by selectively empowered quasi-state apparatuses and indirect techniques for self-management, which together have normalised and instituted the rationalities of neoliberal thinking and its postpolitical form into everyday planning and regeneration practices. As planning has become embroiled in these various institutional entanglements and expectations, there appears to have been a narrowing of its intellectual horizons, to the extent that planners rarely seem to offer an alternative to the mainstream paradigm and potentially disruptive ideas if they are seen as little more than 'extreme' or fanciful ideas. Even ideas with potentially radical credentials, such as ecotowns, come to be neutralised and tamed by the requirements of planning, such that even the promise that they might operate as privileged state spaces of experiment soon became tamed. If ecotowns were to be bold experimental spaces for ecoplanning, they soon instead became normalised into routinised planning debates about legitimacy, practicability, accountability, and local acceptability.

Thinking about soft spaces of governance in these terms helps highlight a range of issues about how neoliberalisation evolves both in general terms and also specifically in relation to planning as a form of neoliberal spatial governance. Soft spaces have been the vehicle for a series of narrowly conceived neoliberal experiments in promoting different forms of high economic growth, albeit in a rather disconnected fashion, such that different soft spaces 
might have contradictory and rather loose aims. Paradoxically perhaps, soft spaces have also performed a coordinative function that in part reflects a failure of planning to live up to its promises of an improved role in public consultation and policy coordination. But whilst soft spaces may be a form of disruption to mainstream planning, in practice they are almost the opposite of the disruptions required of politics proper, which in Rancière's terms require the translation of specific demands into universal demands for equality. There are exceptions to this, spaces of resistance, but most officially sanctioned soft spaces are about maintaining the existing social order rather than challenging and transforming it.

To summarise, in this paper we have developed a framework that provides fresh explanatory power to understanding the spatial and temporal variability of governance arrangements of planning; not least in how soft spaces and fuzzy boundaries are used selectively and creatively as an instrument of neoliberal governmentality to break down old rigidities and attempt to rework interscalar governance relationships. In the process, this new form of neoliberal governmentality has reworked the nature of planning itself, as it has become less focused on the visionary and imagining the 'impossible' and more concerned with pragmatic negotiations around the reductive sense of the 'sensible' and the 'necessary' in the context of the seeming inevitability of market-based forms of policy rationality. This loss of a wider sense of purpose is important both for planning itself and for society more generally.

\section{References}

Albrechts L, 2006, "Bridge the gap: from spatial planning to strategic projects” European Planning Studies 14 1487-1500

Allmendinger P, 2011 New Labour and Planning. From New Right to New Left (Routledge, London)

Allmendinger P, Haughton G, 2009, "Soft spaces, fuzzy boundaries and metagovernance: the new spatial planning in the Thames Gateway” Environment and Planning A 41 617-633

Allmendinger P, Thomas H (Eds), 1998 Urban Planning and the British New Right (Routledge, London)

Brenner N, 2004 New State Spaces: Urban Governance and the Rescaling of Statehood (Oxford University Press, Oxford)

Brenner N, Peck J, Theodore N, 2010a, "Variegated neoliberalization: geographies, modalities, pathways" Global Networks 10 182-222

Brenner N, Peck J, Theodore N, 2010b, “After neoliberalization?” Globalizations 7 327-345

Communities and Local Government, 2011 Draft National Planning Policy Framework July, Department for Communities and Local Government, London

Conservative Party, 2010 Open Source Planning Conservative Party, London

Counsell D, Haughton G, 2006, "Sustainable development in regional planning: the search for new tools and renewed legitimacy" Geoforum 37 921-931

Davoudi S, Strange I, 2009, "Space and place in twentieth century planning: an analytical framework and an historical overview", in Conceptions of Space and Place in Strategic Spatial Planning Eds S Davoudi, I Strange (Routledge, London) pp 7-42

Dühr S, 2011, "Baltic Sea, Danube and macro-regional strategies: a model for transnational cooperation in the EU?”, working paper, May; http://www.ru.nl/scapes/koppeling/gpm/duhr/

Faludi A K F, 2010, “Beyond Lisbon: soft European spatial planning” Disp 182(3) 14-24

Gallent N, Hamiduddin I, 2012, "Housing and growth under the new regime”, in Changing Gear-Is Localism the New Regionalism? Eds M Ward, S Hardy (The Smith Institute, London) pp 107-116

Harrison J, 2010, "Networks of connectivity, territorial fragmentation, uneven development: the new politics of city-regionalism” Political Geography 29 17-27

Haughton G, 1999, "Trojan horse or white elephant? The contested biography of the life and times of the Leeds Development Corporation” Town Planning Review 70 173-190

Haughton G, 2012, "Planning and growth”, in Changing Gear-is Localism the New Regionalism? Eds M Ward, S Hardy (The Smith Institute, London) pp 95-105 
Haughton G, Counsell D, 2004 Regions, Spatial Strategies and Sustainable Development (Routledge, London)

Haughton G, Allmendinger P, Counsell D, Vigar G, 2010 The New Spatial Planning: Territorial Management with Soft Spaces and Fuzzy Boundaries (Routledge, London)

Heley J, Jones M, 2012, "Devolution and Wales-fiddling with spatial governance whilst the economy burns", in Changing Gear-is Localism the New Regionalism? Eds M Ward, S Hardy (The Smith Institute, London) pp 55-65

Hildreth P, Bailey D, 2012, "What are the economics behind the move to LEPs?” in Changing Gear-is Localism the New Regionalism? Eds M Ward, S Hardy (The Smith Institute, London) pp 25-33

HM Government, 2010a Local Growth. Realising Every Place’s Potential Cm 7961, (The Stationery Office, London)

HM Government, 2010b Decentralisation and Localism Bill (The Stationery Office, London)

Inch A, 2010, "Culture change as identity regulation: the micro-politics of producing spatial planners in England" Planning Theory and Practice 11 359-374

Lemke T, 2002, "Foucault, governmentality and critique” Rethinking Marxism 14(3) 49-64

Lemke T, 2007, “An indigestible meal? Foucault, governmentality and state theory” Distinktion: Scandinavian Journal of Social Theory 8(2) 43-64

Lovering J, 2007, “The relationship between urban regeneration and neoliberalism: two presumptuous theories and a research agenda” International Planning Studies 12 343-366

Luukkonen J, Moilanen H, 2012, "Territoriality in the strategies and practices of the Territorial Cohesion Policy of the European Union: territorial challenges in implementing 'soft planning'” European Planning Studies 20 481-500

Marchart O, 2007 Post-Foundational Political Thought. Political Difference in Nancy, Lefort, Badiou and Laclau (Edinburgh University Press, Edinburgh)

Martínez-Alier J, Pascual U, Vivien F-D, Zaccai E, 2010, “Sustainable degrowth: mapping the context, criticisms and future prospects of an emergent paradigm” Ecological Economics 69 1741-1747

Metzger J, Schmitt P, 2012, "When soft spaces harden: the EU strategy for the Baltic Sea Region” Environment and Planning A 44 263-280

Mouffe C, 2005 On the Political (Routledge, London)

ODPM, 2003 Sustainable Communities in the South East Office of the Deputy Prime Minister (The Stationery Office, London)

Oosterlynck S, Swyngedouw E, 2010, "Noise reduction: the postpolitical quandary of night flights at Brussels airport” Environment and Planning A 42 1577-1594

Paasi A, 2010, “Commentary. Regions are social constructs, but who or what 'constructs' them? Agency in question" Environment and Planning A 42 2296-2301

Painter J, 2008, “Cartographic anxiety and the search for regionality” Environment and Planning A 40 342-361

Peck J, 2010 Constructions of Neoliberal Reason (Oxford University Press, Oxford)

Peck J, Theodore N, 2007, “Variegated capitalism” Progress in Human Geography 31 731-772

Peck J, Tickell A, 1992, "Local modes of social regulation? Regulation theory, Thatcherism and uneven development” Geoforum 23 347-363

Peck J, Tickell A, 1995, “The social regulation of uneven development: 'regulatory deficit', England's South East and the collapse of Thatcherism” Environment and Planning A 27 15-40

Peck J, Tickell A, 2002, “Neoliberalizing space” Antipode 34 380-404

Raco M, 2005, "Sustainable development, rolled-out neoliberalism and sustainable communities" Antipode 37 324-347

Rancière J, 1995 On the Shores of Politics (Verso, London)

Rancière J, 1999 Disagreement: Politics and Philosophy (University of Minnesota Press, Minneapolis, MN)

Rancière J, 2001, “Ten theses on politics” Theory and Event 5(3)

Rancière J, 2006 Hatred of Democracy (Verso, London)

Rose N, Miller P, 1992, "Political power beyond the state: problematic of government” British Journal of Sociology 43 173-205 
Searle G, Bunker, R, 2010, “New century Australian spatial planning: recentralization under Labor” Planning Practice and Research 25 517-529

Stead D, 2011, "Policy and planning brief. European macro-regional strategies: indications of spatial rescaling?” Planning Theory and Practice 12 163-167

Swyngedouw E, 2007, “Impossible 'sustainability' and the postpolitical condition”, in The Sustainable Development Paradox Eds D Gibbs, R Krueger (Guilford Press, New York) pp 13-40

Tewdwr-Jones M, 2002 The Planning Polity (Routledge, London)

Thornley A, 1993 Urban Planning Under Thatcherism. The Challenge of the Market 2nd edition (Routledge, London)

Vigar G, Healey P, Hull A, Davoudi S, 2000 Planning, Governance and Spatial Strategy in Britain: An Institutionalist Analysis (Macmillan, Basingstoke, Hants)

Waterhout B, 2010, "Soft spaces and governance: the transformation of planning”, in Global Challenges and Local Responses Eds A Balducci, K Taipale (Aesop, Helsinki) pp 1-19 